\title{
THE ROLES OF ISLAMIC ORGANIZATIONS IN CIVIL SOCIETY AND POLITICAL SOCIETY: Malaysia and Indonesia Compared
}

\author{
AISAH PUTRI $^{\text {I }}$
}

\begin{abstract}
In both Malaysia and Indonesia, Islamic organizations have played significant roles not only in civil society, but also in political society. By contrasting the Malaysian and Indonesian cases, this paper builds a notion arguing that it is possible for the Islamic organizations in civil society to objectively and actively oversee the state even when they are strongly linked to political parties. However, it needs specific conditions, namely a democratic system, a weak political coalition, and an independent integration process to allow Islamic organizations to move into political society. This argument is also antithetical to a popular neo-Tocquevilleans' argument that civil society should be separated from political society to function effectively.
\end{abstract}

Keywords: Islamic organization, civil society, political society, Indonesia, Malaysia

\begin{abstract}
Abstrak
Di Malaysia dan Indonesia, organisasi Islam memiliki peran yang signifikan tidak hanya di dalam masyarakat sipil tetapi juga di dalam masyarakat politik. Dengan membandingkan kasus Malaysia dan Indonesia, makalah ini membangun pemikiran bahwa sangat mungkin organisasi Islam di dalam masyarakat sipil untuk secara objektif dan aktif mengawasi negara, meskipun di saat yang bersamaan memiliki hubungan kuat dengan partai. Namun, hal ini membutuhkan kondisi yang spesifik diantaranya sistem demokrasi, koalisi politik yang lemah, dan proses integrasi organisasi kedalam masyarakat politik yang independen. Argumentasi ini menjadi anti-tesis dari pandangan Neo-Tocquevilleans yang popular bahwa masyarakat sipil harus terpisah dari masyarakat politik untuk dapat menjalankan fungsinya.
\end{abstract}

Kata kunci: organisasi Islam, masyarakat sipil, masyarakat politik, Indonesia, Malaysia

\section{INTRODUCTION}

Based on his study in Italy, Putnam (I993, p. I07-I08) builds an argument that a religious organization should be excluded from civil society because it tends to make the members look inward toward its own community, not to the broader society. ${ }^{2}$ Nevertheless, it is not possible for Islamic organizations to be excluded from civil society in Muslim majority countries

such as Malaysia and Indonesia. Here, an Islamic organization is defined as a voluntary institution or association, which adopts Islamic values as its ideology or brings Islam as its organizational identity. The key to identifying an Islamic organization is its organizational motivation. Social actions run by the organization are motivated by Islamic conviction and Islamic faith (Freedman, 2009, p.II2).

\footnotetext{
I Researcher at Centre for Political Studies, Indonesian Institute of Sciences (LIPI), Jakarta, Indonesia. Email: aisahputrib@gmail.com

This paper was presented in the SAIS Asia Conference 2015: "Power in Asia" held by the School of Advanced International Studies (SAIS), Johns Hopkins University in Washington, DC, on Friday, April I7, 2015. Thank to Meredith Weiss, Ph.D. and Kikue Hamayotsu, Ph.D for all the advice to complete this paper.

2 By adopting a definition proposed by Muthiah Alagappa, this paper defines civil society as "a realm in the interstices of the state, political society, the market, and the society at large for organization by non-state, non-market groups that take collective action in the pursuit of the public good" (Alagappa, 2004, p. 32).

Copyright $\bigodot_{20 I 6}$ The Author, (20I6 Deputy of Social Sciences and Humanities. All rights reserved. Printed in Indonesia. Journal of Indonesian Social Sciences and Humanities (JISSH); Vol. 6, Issue 2, (20I6), Pp. 29-42. ISSN: I979-843I.
} 
Islamic organizations in Indonesia and Malaysia play a significant role in society and are a crucial component of civil society. Islamic organizations play important roles in the community by giving social services, enhancing civil liberties, playing a watchdog role to the state, and soon (Mitsuo,20oI, p.I2). In this sense, they bring a substantial contribution to strengthen rather than to overturn the democratic state. It is in line with a Malay-term, masyarakat madani, which is often assumed to be synonymous with civil society. ${ }^{3}$ The root of madani is a term 'din' or religion, which shows that masyarakat madani is a place or community where the Islamic values are perfectly adopted by society (Muhammad I998, p. I5-I6;Farid,20I0, p. I73). In this framework, civic-minded Muslims discuss issues of pluralism, social justice, tolerance, democratization, and morals of individuals (Muhammadi998, p. I5-I6; Farid, 2010, p. I73; Weiss, 2004, p.263). Islam is not only an identity and religion, but it is also strongly related to public norms and public life (Karakas, 2007, p. 3). Therefore, it is unreasonable to ignore the existence of Islamic organizations in civil society. Instead of being an 'alternative to the civic community,' ${ }^{4}$ Islamic organizations in Malaysia and Indonesia are certainly part of civil society.

Besides playing important roles in civil society, Islamic organizations in Malaysia and Indonesia are closely linked to political society -which is essentially political partiesand to the state. 5 There are two ways for the organizations to connect with the state. They are either co-opted by the state or transform themselves into political parties. Here, the paper discusses the political dynamic among major Islamic organizations that have connections

3 This term was introduced by Muhamad Naguib al-Attas, a Malaysian intellectual, in the early I990's, and was popularized later by Anwar Ibrahim, a Malaysian politician and Islamic leader and NurcholisMadjid, an Indonesian Islamic intellectual (Muhammad, I998, p. I5; Tajuddin 2012, p. I63).

$4 \quad$ Putnam categorizes religious groups as "an alternative to the civic community" but not as a part of civil society (I993, p. IO7).

5 Regarding Alfred C. Stepan, political society is an arena in which political parties arrange themselves for political contestation to gain control over public power and the state apparatus (I988). It is different from the state as defined by Joel S. Migdal: "a political organization that is the basis for government in a given territory and then leaves it at that" (I988, p. I8). with political parties, including the Malaysian Islamic Youth Movement (ABIM) in Malaysia and Nahdlatul Ulama (NU) and Muhammadiyah in Indonesia. They enter political society by having affiliations with political parties in a direct or an indirect manner. However, once the Islamic organizations enter political society, it does not necessarily mean that they will stay. In fact, their relationships with political parties may change several times. This situation is clearly shown below by Table $\mathrm{I}$.

Table I. A Typology of Islamic Organization in Indonesia and Malaysia ${ }^{6}$

\begin{tabular}{|c|c|c|}
\hline Country & $\begin{array}{l}\text { Affiliated Islamic Organizations } \\
\text { (apart of political society) }\end{array}$ & $\begin{array}{l}\text { Non-Affiliated Islamic } \\
\text { Organizations (not } \\
\text { a part of political } \\
\text { society) }\end{array}$ \\
\hline Malaysia & $\begin{array}{l}\text { Malaysian Islamic Youth Move- } \\
\text { ment (ABIM) (1982-1998, } \\
\text { 2003-now), Islamic Dakwah } \\
\text { Foundation Malaysia (YADIM), } \\
\text { All-Malaysia Muslim Welfare } \\
\text { Organization (PERKIM), Council } \\
\text { for the Welfare of Muslim } \\
\text { Women (LKPI) }\end{array}$ & $\begin{array}{l}\text { Darul Arqam (DA), } \\
\text { Sisters in Islam (SIS), } \\
\text { ABIM (1971-1982, } \\
\text { 1998-2003) }\end{array}$ \\
\hline Indonesia & $\begin{array}{l}\text { Nahdlatul Ulama (NU) (1945- } \\
\text { 1980s; 1999-now), Muham- } \\
\text { madiyah (1945-1960, 1999- } \\
\text { now), Association of Indonesian } \\
\text { Muslim Intellectuals (ICMI), } \\
\text { the Indonesian Ulema Council } \\
\text { (MUI) (1975-1999),Sarekat } \\
\text { Islam (SI) (1920-1977) }\end{array}$ & $\begin{array}{l}\text { Liberal Islam Network } \\
\text { (JIL), Muhammadi- } \\
\text { yah (1990s-1999), } \\
\text { NU (1980s-1999), } \\
\text { Sarekat Islam (SI) } \\
\text { (1906-1919),Per- } \\
\text { satuan Islam or The } \\
\text { Unity of Islam (Persis) } \\
\text { (1923-now) }\end{array}$ \\
\hline
\end{tabular}

As shown in Table I, major Islamic Organizations, such as ABIM in Malaysia, NU and Muhammadiyah in Indonesia, have often changed their political affiliations. What is interesting about this phenomenon is how the organizations' roles of overseeing the state change when they change affiliation. For example, when ABIM in Malaysia moved into political society, it lost its ability to criticize the state. When ABIM became affiliated with a political party it tended to follow all the state's decisions and policies. This is different from the non-affiliated ABIM which tended to be critical of the state. This can be seen with other affiliated Islamic organizations. In contrast to

$6 \quad$ Not all of the Islamic organizations in Malaysia and Indonesia are mentioned in this table. The table only mentions major organizations that are discussed in this paper. 
ABIM, Muhammadiyah and NU in Indonesia are able to objectively be a watchdog to the state, even when they are affiliated with political parties. It raises an important question: why can Indonesian Islamic organizations maintain their supervisory function when they are affiliated with parties, while the Malaysian organizations cannot?

This paper argues that there are three reasons determining the different behaviors of Islamic organizations entering political society in Malaysia and Indonesia: the political system, the form of the political coalition and the integration process of civil society into political society. This paper finds that it is possible for Islamic organizations to carry out their function in civil society when they have affiliations with political parties. They can still play their watchdog role to oversee the state and to protect society from state tyranny, even though they are part of political society. However, it needs specific conditions, namely that the state must be a democracy, the integration process of the organizations into political society should not be regulated by the state, and the political coalition is not defined by a strict and rigid format.

In the following section, the paper explores the neo-Tocquevilleans' notion about the state-civil society relationship as a basic theoretical framework in order to understand the relationship between Islamic organizations and the state in Indonesia and Malaysia. It then continues to describe the developments of Islamic organizations in Malaysia and Indonesia after independence in the mid- $20^{\text {th }}$ century by focusing more on how these organizations relate to the political parties, the state and how they function within civil society. It aims to show the different methods of Indonesian and Malaysian Islamic organizations in dealing with the state when they are within political society and when they are not. The paper ends with the analysis of major factors differentiating the methods and shows when the Islamic organizations can play substantial roles in both civil society and political society at the same time and when they cannot.

\section{THE ANALYTICAL FRAMEWORK}

Among the scholars who study civil society, Tocqueville's concept of civil association -which essentially is that civil society, brings an important perspective to the relationship between civil society and the state. By observing French history and American democracy, Tocqueville builds a notion that civil society will function as a guard against domination by a single interest, to act in local interests and the national common good, to limit state power and to prevent abuse by the state. His 'civil society' is operating in conditions of political freedom and limited state power, which means that the state would restrain itself to the political realm and guarantee the legal framework to support civil society (Tocqueville,2004, p. 604-606; Alagappa, 2004, p. 30).

By developing the theories built by Tocqueville, the neo-Tocquevilleans develop an argument about the ideal form of civil society/political society relationship and the civil society/state relationship. Different from Tocqueville who places civil society as a key site for the democratic governance, neo-Tocquevilleans put the state as the locus of political activities and view civil society as a supporting structure to democratize the state (Alagappa, 2004, p. 4I). They position civil society as an institution independent from the state and from political society which aims to protect the public sphere from an intrusive state, to influence state policy and to alter the regime type from authoritarian to democratic. The functions of civil society then become the release of society from a totalitarian ideology of the party state, improving social autonomy, civil liberties and human rights, and producing democratic space outside political parties and the state (Alagappa, 2004, p. 3I).In this theoretical framework, the civil society would be the alternative power center outside the state and the political party (Riley, 2005, p. 289). However, the presence of civil society would not be considered as a challenge by the state or political society, because its main purpose is not to change the political society-state relationship or to capture state power (Alagappa, 2004, p. 3I). 


\section{ISLAMIC ORGANIZATIONS IN MALAYSIA}

Malaysia is a Southeast Asian country that is fundamentally defined by its racial and religious pluralism; however the majority of Malaysians are Muslim (61.3\%)(Weiss, 2004,p. 259).As a majority Muslim country, Islam is an important aspect in social and political life in Malaysia. It has become a core element in the country not only a symbol of Malay cultural identity, but also an ideological foundation of organization in civil society (Hassan, 200I, p. 77). Islam is the religion of the federation and the state manages a wide array of Islamic affairs, for example Syariah law is implemented to deal with personal matters among Muslims. ${ }^{7}$ Recognizing the embedded-ness of Islam in society leads the government to perceive Islamic organizations as a representative of Islamic communities and to give them some public space for their activities. The development of Islamic organizations in Malaysia has become more visible and significant since the I960s, which was known as the period of 'Islamic resurgence' or 'Islamic revivalism' (Hassan, 2009, p. 62).

The Islamic resurgence made the government realize that Islamic organizations, especially the National Association of Malaysian Muslim Students (PKPIM), ABIM and DA, could be possible political challengers to the authoritarian political system. ${ }^{8}$ The PKPIM, $\mathrm{ABIM}$ and DA were listed as threats to the state. As Malaysia was a majority Muslim country the potential of these organizations and Muslims in general to be critical of, or even oppose the state was seen to be great. Therefore, the government established and sponsored a number of Islamic organizations, such as YADIM, PERKIM, LKPI, in an attempt to demobilize the powerful Islamic organizations that might challenge the government. 'YADIM, PERKIM and LKPI were

\footnotetext{
$7 \quad$ Malaysia also applies civil law, which has more authority to control society (Aziz and Shamsul, 2004, p. $352)$.

8 Scholars, including Andreas Ufen and William Case categorize Malaysia as an electoral authoritarian state since the government runs the state with a centralistic government that is not elected by fully competitive and open elections (Ufen, 2009, p. 320; Case, 2006, p. 96). $9 \quad$ Yayasan Dakwah Islamiah Malaysia-Islamic Dakwah Foundation Malaysia (YADIM) is an organization formed by Allahyarham Tun Haji Abdul Razak bin Hussin, the Second Prime Minister of Malaysia on January 25, I974 aiming to consolidate the activities of Islamic organizations and NGOs with The State Principle (www.yadim.
} com.my accessed on November 2I, 20I6); Pertubuhan Ke- dependent on the government's patronage, and they had greater access to the policy-making process, financial assistance and other facilities. In return, they were seldom critical of the government or vocal in promoting new ideas of democracy. Their functions were solely in maintaining an Islamic image for Malaysia and the notion of UMNO as the guardian of Islam (Hassan, 2004, p. 98-99, IOI-IO2).

ABIM is one of Malaysia's independent Islamic organizations that were influential in the Islamic resurgence period. ${ }^{\mathrm{I}}$ Initially their agenda addressed only the moral issues in daily life, namely providing Islamic education, social services, improving the economy of Muslim communities and the like. Then, after it gained strong support from Muslims, it started to take a political stance. It held programs related to democratic participation, civil rights - especially equality among racial groups- and creating a society defined by Islamic principles. It also criticized the government, in term of its unIslamic values and practices (Hassan, 2004, p. I03; Hamid, 2003,p. 362-363; Hassan, 2009, p. 69-7I; Bakar, 200I, p. 67; Liowand Pasuni, 2015, p. 52).

ABIM changed its political stance from opposing the state and affiliating with the opposition in the I97os to supporting the state and UMNO in the early I980s. Initially, some members of ABIM built a strong relationship with Pan-Malaysian Islamic Party (PAS), an opposition party. Many ABIM members joined PAS because they shared the same commitment to strengthening the role of Islam in Malaysian society (Hassan, 2004, p. I03; Hamid, 2003, p.

bajikan Islam Se-Malaysia or All Malaysia Muslim Welfare Association (PERKIM) is an Islamic and social welfare organization founded in I960 whose goal is promoting Islam as a national religion (www.oxfordislamicstudies. com accessed on November 2I, 20I6); Lembaga Kebajikan Perempuan Islam or Council for Welfare of Muslim Women (LKPI) was established by Queen Raja Permaisuri Agong Tunku Khushiah, in I960 and aims to protect Islamic women's rights, particularly within the context of Malaysia state's Islamic laws (Hassan, 2004, p. IOI-IO2). These three organizations are formed and supported by the government of Malaysia (Hassan, 2004, p. IOI).

Io Besides ABIM, DA was another influential Islamic organization that was critical of the government. It challenged the government by criticizing its failure to implement Islamic law, by accusing the government of corruption and by proposing the idea of referendum (Fauzi, 2003, p. 364-365). It impacted a negative response from the government that finally banned the organization in 1994 after the Malaysian National Fatwa Council declared that it had deviated from the true teachings of Islam (Hassan, 2004, p. I08). 
362-363; Hassan, 2009, p. 69-7I; Mohamad, 200I, p. 67). The stronger PAS became a threat for UMNO and the state. By having ABIM's members within the party, PAS would be able to attract more Muslims to vote for them in the elections. UMNO, whose image was as a secular party, might have lost the election if PAS could attract more Muslim support than UMNO. Facing this situation, UMNO and the state, led by Mahathir Mohammad, changed their orientation to be more Islamic ${ }^{\mathrm{II}}$ and co-opted Anwar Ibrahim, the charismatic leader of ABIM, into UMNO in 1982 (Hassan, 2004, p. I05; Hassan, 200I, p. 8I; Weiss, 2006, p. II4). This led to many members of ABIM, who supported Anwar, to become members of UMNO, and so ABIM, which was initially critical of the state, became less critical (Hassan, 2004, p. I05-I06). As with other co-opted organizations, ABIM followed and agreed with the political decisions made by the state. Nonetheless, it is important to understand that ABIM was also part of policy making since many members or its former members worked for the party or the government. Thus, ABIM had more political power to influence government policy, but at the same time, it had less power to criticize the regime.

The political stance of ABIM changed after the financial crisis hit Malaysia and created insurgencies in I997. After having a confrontation with Mahathir about Malaysian economic policies, Anwar brought forward an idea of political reform. He had toured the country for eighteen days to give lectures on justice, the evil side of Mahathirism, corruption and the urgency of political reform and democracy (Weiss, 2006, p. I29). Anwar's attempts to promote political reform were supported by ABIM, ending ABIM's support of UMNO and the state. Together with other Islamic organizations and nonIslamic organizations, they used their grassroots networks to mobilize thousands of Malays to support Anwar's reformation movement and

\footnotetext{
II Mahathir Mohamad pursued Islamization policies in 1982 by establishing Islamic banks, Islamic universities, and by implementing Islamic ethics in the administrative services (Mohamad, 200I, p. 66-69; Liow and Pasuni, 2015, p. 52). UMNO also changed its image from a secular party to a progressive-moderate Islamic party (Hassan, 2004, p. I05-I06).
}

to sway popular opinion against the National Front (BN), a major coalition of political parties in Malaysia -that included UMNO amongst others (Weiss,2006, p. I29; Mitsuo,200I, p. Io). This movement was also supported by political parties that later were institutionalized as a multiparty opposition coalition, the Alternative Front (BA) (Gomez, 2007, p. I).

ABIM was certainly one of the leading Islamic organizations promoting democracy and criticizing the state in the late I99os. It, however, changed its political orientation to be more conservative after the failure of the reformation movement to bring a more democratic regime to Malaysia ${ }^{12}$ and after a leadership transition in 2003. The new leader, Yusri Mohamad stated that reformasi was an unfortunate episode of the organization because ABIM had become less powerful in contemporary Islamism. In order to revive ABIM's reputation, he became more pragmatic by changing the modernist $\mathrm{ABIM}$ into a more conservative organization. By becoming a conservative organization, ABIM automatically changed its objectives to democratize the state -as it had proposed during the reformation period- ABIM becoming less threatening to the state. To fix its relationship with the state, ABIM again changes its political orientation to be a supporter of UMNO and Abdullah Badawi's government (Hamid, 2008, p. 225-227;Amal and Rizal, 2004, p. 157).

The changing of ABIM's orientation can be seen clearly from its political stance on the issue of apostasy. The issue is about the disagreement between Article II of the constitution which states that the citizen has the right for freedom of religion and Syariah law that does not allow Muslims to leave their faith. It became a huge debate after the case of Lina Joy in 1998, in which the state prohibited a Muslim to convert to Christianity. Many organizations, including the Sisters in Islam, protested against the government on the prohibition of the conver-

I2 Although the democratic movement failed to change the regime, it marked a shift in Malaysian politics. Now, the Malays have become more critical of the government and they have become more willing to find political alternatives than before (Weiss, 2006, p. I43, I66I67, 250). 
sion of Muslim Malays and proposed complete freedom of religion as stated in Article II. $^{\mathrm{I3}} \mathrm{On}$ the contrary, ABIM agreed with the state and saw Article II as a threat to Islam and to the right of Muslims to live under Islamic principles (Lemiere, 2007,p. 46-47). This political stance is quite different from ABIM in the reformasi period when it supported the idea of freedom and tolerance (Hamid, 2008, p. 225-227). This new viewpoint is not surprising since ABIM had chosen to support the government.

Based on the Malaysian experience, the electoral authoritarian system adopted by the state has a huge impact on the interaction between the Islamic organizations in civil society with the political parties and the state. The system has made the state able to co-opt organizations in order to gain support to sustain its dominance. It is essential for the state to obtain endorsement from the Islamic organizations since they have a huge number of constituents, more than 60\% of the Malaysian population is Muslim. The state co-opted Islamic organizations by inviting them to be members of the state-party, UMNO, just as it did to ABIM in I982. By having its members in UMNO, ABIM gained power in influencing policies, but in return, it gradually became removed from its supervisory function, as a part of civil society, to oversee the state. Theoretically, it has proven the neo-Tocquevillean's argument that to function; civil society should be separate from the state and the political parties. However, in the Malaysian context, it is difficult to be a powerful and an influential Islamic organization without playing a role in political society or supporting the state because of the state's strong powers to control all political aspects, including aspects within civil society.

\section{ISLAMIC ORGANIZATIONS IN INDONESIA}

Similar to Malaysia, Islam in Indonesia also plays an important role in the social and political realm. Indonesia is the world's fourth most populated country in the world, with about 87 percent of the 238 million populations identi-

I3 Initially, Sisters in Islam (SIS) established in I988, was a research and advocacy group for women focusing on women's rights under Islamic law. It then registered as an NGO or organization of women professionals in 1993 (Liow, 2009, p. I24). fying as Muslims (www.bps.go.idaccessed on November 19, 20I6). This makes Indonesia the largest Muslim-majority country in the world (Buehler, 2009, p. 5I). Although Indonesia is a Muslim-majority country, it is not an Islamic theocracy. Indonesia acknowledges six official religions: Islam, Protestantism, Catholicism, Hinduism, Buddhism, and Confucianism. Indonesia, however, does not give any special privilege for Islam. Islam, nevertheless, has played an important role in society, not only providing an identity for individuals, but also by becoming the ideological basis of many organizations in the country. Generally, the Islamic organizations are divided into two factions: traditionalist, such as NU, which are strict with mazhab to understand Al'Quran, and modernist, such as Muhammadiyah, which promotes an individual reasoning to understand Al'Quran and hadist (Mietzner, 2009, p. 69-70). ${ }^{\text {I4 }}$

After its independence in 1945 , Indonesia has experienced several different political systems: democracy under Soekarno's leadership was divided into liberal democracy (1945-1958) and guided democracy (I959-I966), the authoritarian system under Suharto's regime (I966-I998), and electoral democracy commonly known as the reformation period (I998-present). The changing political systems in Indonesia have had a tremendous effect on the relationship between Islamic organizations and political society. This part will discuss the idea that a similar relationship between Islamic organizations and political society developed in Indonesia during the democratic era in I945-I958, and in the reformation era. In both periods, Islamic organizations become active not only in civil, but also in political society.

Islamic organizations, such as Sarekat Islam (SI), Nahdlatul Ulama, and Muhammadiyah, played important roles in the fight against colonialism and the fight for independence. Many Muslim leaders and activists from these organizations, especially those from SI, aimed to establish Indonesia as an independent state based on Islam (Hefner, 200o, p. 38; Al Anshori,

I4 This typology is a classic classification that is able to explain the development of Indonesian Islamic organizations through generations and political periods. Therefore, it is relevant for this paper that explains Islamic organizations from pre-independence era (before I945) to the reform era (after I999). 
p. 97-98, 103). However, after Indonesia got its independence in I945, the consensus of Indonesian leaders decided to adopt Pancasila as the foundation of the state and rejected the idea of an Islamic state. Realizing that Islam was to play no special role in the constitution of Indonesia, Muslim activists were disappointed and they tried to find ways to change the constitution.

Under the liberal democracy, Muslim activists found an opportunity to change the state's leader through elections. Realizing that they had strong constituency, Muslim leaders believed that they could establish an Islamic state by winning the first Indonesian election in I955. They would win the election and then change the constitution by the formal policy making process in parliament (Hefner,2000, p. 43; Madinier, 2015, p. 349). Therefore, representatives of the main Islamic Organizations, such as Muhammadiyah and NU, joined to form Masyumi Party in 1945 (Madinier, 2015, p. 348-349). However, in 1952 , NU withdrew from Masyumi Party due to ideological reasons and later, created its own political party (Lee, 2004, p. 9I). ${ }^{\text {I5 }}$ Surprisingly, the Islamic parties received only about $43 \%$ of electoral votes (Masyumi $20.9 \%$ and NU $18.4 \%$ ), and could not gain a parliamentary majority (Hefner, 2000, p. 43). ${ }^{16}$ As a result, they did not have enough political power to constitutionally change the state's ideology.

Although Masyumi and NU did not have a majority seat in parliament, they played important roles in Indonesian politics under Soekarno's regime. Masyumi and NU effectively used their supervisory function to oversee and to criticize Soekarno's government and policies. Both Masyumi and NU rejected Soekarno's conception of guided democracy, which had a strong tendency to be a totalitarian regime. They argued that adopting guided democracy

I5 NU withdrew its support from Masyumi party because of ideological differences, for instance, NU disagreed with Masyumi's casual nature in their acceptance of the Indonesian language while praying and its tolerance of wearing Western clothing while praying (Lee, 2004, p. 9I).

I6 Beside NU and Masyumi Party, there were other Islamic parties competing in the election, such as Partai Syarikat Islam Indonesia or Indonesian Islamic League Party (PSII), Pergerakan Tarbiyah Islamiyah or Islamic Tarbiyah Union (Perti), and Partai Persatuan Tharikah Islam or Islamic Tharikah Unity Party (PPTI). However, they only got less than $3 \%$ of the vote in the election. would lead to the tyranny of the state and would harm society (Assyaukanie, 2009, p. 76; Hefner, 2000, p. 86; Madinier, 2015, p. 244-245, 26I).

All NU leaders and figures agreed to reject the presence of communists in the government during the Soekarno era. Nevertheless, on reacting to the idea of guided democracy, NU was divided into two factions, those who rejected and those who supported the idea. On one hand, KH. M. Dachlan, Vice Chairman of Tanfidziyah NU, and Imron Rosjadi (Chairman of Anshor NU) were leaders of NU who strongly rejected the idea of guided democracy. They were supported by other influential NU figures such as Kiai Bisri Syasuri and Kiai Ahmad Siddiq. On the other hand, Kiai Wahab Chasbullah, an influential leader of NU, who admired Soekarno, gave his support for guided democracy. Chasbullahwas followed by other NU's figures, including Masjkur, Idham Chalid, Zainul Arifin, Saifunddin Zuhri and Ahmad Sjaichuwho did not form any meaningful opposition to the Soekarno government (Bruinessen, I994, p. 73-74).

Masyumi was a political detractor of Soekarno and his policies. Masyumi not only rejected the notion of guided democracy, they envisaged it would bring tyranny. They were also critical of the taxation, financial and economic policies of the government. Masyumi even made bold moves on parliament to oppose Soekarno's government and policies. By using its political power in parliament, Masyumi rejected the national budget plan proposed by the government in 1960 (Assyaukanie,2009, p. 76; Hefner, 2000, p. 86).

Facing resistance from Masyumi, Soekarno declared Masyumi as a barrier to the completion of the Indonesian revolution, and he banned it in 1960 (Warjio and Ginting, 2006, p. 36-37). Soekarno was able to ban Masyumi not only because he was a president, but also because the political system at that time allowed him to do so. Guided democracy gave more legitimacy for Soekarno to control the country, including the civil and political society. Formally, he did not ban Masyumi because it criticized the government, but it was labeled as a traitor due to its support for the rebel movement, the 
Revolutionary Government of the Republic of Indonesia (PRRI) (Lee,2004, p.92; Hefner, 2000, p. 86).

In I965, Soekarno's regime collapsed due to political and economic chaos after the mass killings of Communists and an attempted coup d'état. Indonesia began a new regime led by Suharto, called New Order. Under Suharto's authoritarian regime, the roles of Islamic organizations were marginalized and were limited only to private religious spheres, including ritual prayer, zakat or almsgiving, marriage, and others (Lee2004, p. 93). NU, nevertheless, was still able to run in the election in I97I and won second place after Golongan Karya (Golkar). However, in I973, the government simplified the party system by forcing parties to meld into three parties: Golkar, the Indonesian Democratic Party (PDI) and the United Development Party (PPP) (Ufen, 2006, p. 9).NU and other Islamic parties, including the the Muslim Party of Indonesia (Parmusi), the Islamic Association Party of Indonesia (PSII) and the Islamic Educational Movement (Perti) were officially merged into PPP. However, in I984, NU withdrew its support of PPP and returned to its original form as a non-political organization. The organization was disappointed with the internal conflict within PPP and the parliament, and with the government's policy to marginalize Islam from public sphere (Ali and Nurhuda, 2008, p. 47-48; Hefner 2000, p. I2I; Haris, I99I, p. 8, I4-I6, 48, 54-77, 85).

The state controlled almost all aspects relating to the activities of Islamic organization using co-option and suppression; for instance, it established the Council of Indonesian Ulama (MUI), the highest state sponsorship of Islamic organizations to co-opt Muslims to follow the regime's wishes (Lee, 2004, p. 94; Hwang, 2009, p. 53). Unwittingly, however, this allowed more room for Muslims to have frank discussions about politics and public morality within the organizations, especially NU and Muhammadiyah, compared with non-Islamic organizations. The state may have thought that Islamic organizations focusing solely on private issues would not threaten them, but it was these organizations which asserted democracy and political pressure on Soeharto's regime in the I990's. Facing this new threat, the government established the Indonesian Muslim Intellectuals Associations (ICMI) to co-opt prominent Islamic intellectuals, but this failed to stop them from democratizing the state (Hefner 2000, p. 59; Lee, 2004, p. 95). These intellectuals then transformed their ideas into democratic movements, transmitting them to other non-Islamic organizations, and bringing huge pressure to the government. On May 2I, I998, Soeharto could not handle the chaotic situation due to the democratic movement and the economic crisis, and finally resigned from his position as president.

It is undeniable that Islamic organizations and Islamic intellectuals played important roles in changing the Indonesian regime from authoritarianism to democracy. Then, the next question is "what did they do after Indonesia had successfully changed the regime?" They had to make a decision of either being independent from the state or entering politics. Approaching the election in I999, NU and Muhammadiyah decided to create two political parties, the $\mathrm{Na}$ tional Awakening Party (PKB) and the National Mandate Party (PAN). PAN was founded in 1998 by the leader of Muhammadiyah, Amien Rais, to continue the agenda of political reform. The establishment of PAN cannot be separated from Muhammadiyah since PAN's leadership was recruited largely from the latter organization (Mietzner, 2009, p. 256). NU established PKB in 1998 as a space for the political aspirations of NU members (King, 2003, p. I27). ${ }^{17}$ Structurally, both PAN and PKB are different from Muhammadiyah and NU, but the parties are strongly connected to their respective Islamic organizations.

Though NU and Muhammadiyah had strong grassroots support, they failed to bring a victory for their affiliated-political parties. Only few of NU's and Muhammadiyah's constituents

I7 It is important to note that besides PKB, many NU leaders formed several other parties, namely Partai Kebangkitan Nasional Ulama or National Ulama Awakening Party (PKNU), Partai Kebangkitan Umat or United Believers Awakening Party (PKU), and others. Compared to $\mathrm{PKB}$, the other parties are only small parties that failed to receive significant numbers of votes in elections (less than $2 \%$ ). 
voted for PAN and PKB in the elections. Based on the results of parliament elections from 1999 to 20I4, PAN and PKB never got more than $21 \%$ of the total vote (www.kpu. go.id). However, it is important to note that in 1999, although the affiliated parties did not win the majority of seats in parliament, Amien Rais, a former Muhammadiyah's leader, was elected as the chairman of the People's Consultative Assembly (MPR) and Abdurrahman Wahid, a former leader of NU, as the President. They were elected after Amien Rais created a new coalition, known as Central Axis, poros tengah, which consisted of Islamic-oriented parties, namely The Justice Party (PK), The Crescent Star Party (PBB), PAN, and PPP (Kartasasmita, 2013 , p. $279-280,290) .{ }^{18}$ It is important to understand the differences from Malaysia, which has strong and firm political coalitions, the Indonesian political system is characterized by transactional and weak political coalitions. Since the electoral democracy in the I950s party coalitions in Indonesia havebeen fragile, short-lived and transactional. Andreas Ufen argues that the immense fragmentation and polarization are the reasons of weak coalition in Indonesia. Besides, coalitions are in most cases not the result of shared ideologies or of long-term commitment to a specific goal, but are created through pragmatic decisions (2006, p. 8-I6).

Although NU and Muhammadiyah feature in political society, they are able to preserve their supervisory roles and be critical of the state and even of their own former leaders. Since I999, NU and Muhammadiyah with their affiliated parties have several times criticized government policies that are not pro-people. The recent controversy of passing the Mass Organization Bill into law in 2013 is a good example of how Islamic organizations in political society can monitor the state, and how they interact with political parties.

In 2013, the government of Indonesia proposed to amend the 1985 Mass Organization Law in the parliament. The government

\footnotetext{
I8 Although this coalition was initiated by Islamicoriented parties, it eventually was supported by secularparties and groups in parliament, such as Golkar as well as Indonesian Armed and Police Forces (TNI/POLRI).
}

controversially sought to review the activities of mass organization. Muhammadiyah and PAN strongly criticized the government's proposition because it contradicted the constitution which guarantees freedom to make an organization, and they opposed the government's decision to intervene in organizations. Therefore, they rejected the government's attempt to amend the law. A bit different from Muhammadiyah and PAN, NU and PKB did not reject the proposal, but they felt that revision was needed. The parties also disagreed with the article allowing the government to review the organizations. In this case, both PAN and PKB criticized the government, although they were part of the coalition government. Under pressure to review the proposal the government and parliament erased the articles about the state's interference before finally releasing it on July 2013 (www. bbc.co.ukaccessed on July 2, 2013; www.nu.or. idaccessed on July 22, 2013; www.suaramerdeka; accessed on Aprilı, 20I3www.nasionalkompas. comaccessed on July 2, 2013). ${ }^{\text {I9 }}$

Like the Islamic organizations of Malaysia, the Islamic organizations in Indonesia also have a strong relationship with the political parties. The major organizations, including NU and Muhammadiyah, while still part of civil society, have created political parties in order to participate in elections. This becomes a way for them to participate in policy making and to achieve specific goals, such as political reform. Taking part in political society is in direct opposition of a neo-Tocquevillean argument about the ideal form of civil society. According to neo-Tocquevilleans, civil society cannot effectively run effective check and balances, if they are a part of political society. Nevertheless, the Indonesian case shows that NU, Muhammadiyah and Masyumi can still objectively play their watchdog roles, even when they have affiliations with political parties. They have criticized the policies that they believe harm people and have protected the society from the abuse by the state. Here, the Indonesian case challenges the idea proposed by neo-Tocquevilleans.

\section{COMPARING MALAYSIA AND}

I9 The complete links are mentioned in the bibliography. 


\section{INDONESIA}

The previous descriptions have shown how Islamic organizations in Malaysia and Indonesia play roles not only in civil society, but also in political society. The divergence between these two cases is on how they run their checks and balances to oversee the state. When they affiliate with political parties, NU and Muhammadiyah in Indonesia still maintain their function to monitor the state. However, ABIM in Malaysia struggle to maintain this function. Before 2003, ABIM refrained from criticizing the state and merely followed the state's policies. What are the conditions that make these two cases different? This research finds three aspects which led to the different behaviors of Islamic organizations in Malaysia and Indonesia: the political system, the form of political coalition, and the integration process of Islamic organizations into political society.

Firstly, the different types of political systems adopted by Malaysia and Indonesia are significant factors as to why Islamic organizations in those countries have acted differently when affiliated with political parties. Under the Malaysian electoral authoritarian system, the state has strong powers to control all political aspects, including those aspects within civil society. In order to expand and to maintain its political power, the state can co-opt or ban organizations in civil society, especially those considered being powerful and threatening. It also discriminates against organizations that do not have connections with the state or its party by giving more privileges and advantages to those which have a connection. Facing this situation, the only way for the Islamic organizations to survive and to be more influential in society is by supporting the state and its political party. This is the reason why ABIM supported UMNO in 1982 and Badawi's government in 2003.

The Malaysian case is only dissimilar to the Indonesian case during the periods of democratic regime in I945-I959 and in I998-now -i.e. the periods when the Islamic organizations have entered into political society. Under an electoral democracy, the Indonesian government has no power to control or to intervene within civil society. As previously described, the intervention of the state into the civil society only occurred in Indonesia when political regimes were authoritarian, such as Soekarno's guided democracy (I959-I966) and Soeharto's authoritarianism (I966-I998). In Indonesia, electoral democracy has created conditions for political freedom and a limited state. These two conditions have provided more political strength to the Islamic organizations. This is different from the Malaysian case where the Islamic organizations need an affiliation with the state in order to be influential in politics. The experiences of NU and Muhammadiyah show that the Islamic organizations and their affiliated parties can be influential in policy-making, even when they disagree with the state's political stance. In this sense, the electoral democracy creating the political freedom and the limited state is a key factor as to why the Islamic organizations can function; and theoretically, it is in line with Tocqueville's argument about an ideal condition of civil society.

Secondly, the different integration processes of Islamic organizations into political society in Malaysia and Indonesia lead to different conditions for the relationship between the Islamic organizations and the states. In Malaysia, the state has played an important role in integrating the Islamic organization into political society by co-opting its organization members into the governmental party. For instance, Mahathir Muhammad was the person behind the co-option of Anwar Ibrahim into UMNO, which resulted in more ABIM members joining UMNO in the early I980's. This shows that Islamic organizations have not been independent from the state during the integration process into political society. On the contrary, the state did not intervene into the integration process of Islamic organizations into political society in Indonesia. It was the Islamic organizations that made the decision to be part of the political society by creating and transforming themselves into political parties. These processes were independent, without any intervention from the state. Thus, there was no reason for the state to interfere with the Islamic 
organizations, especially to influence or control their political agenda.

Lastly, the political coalition is an essential factor influencing the ability of Islamic organizations and their affiliated parties to oversee the state. Malaysia has a clear and strict form of political coalition, divided into the opposition (Pakatan Rakyat) and the coalition government (Barisan Nasional). They work for a long-term commitment, so it is difficult for the party to change its political orientation once it is allied with one coalition. Therefore, when the Islamic organizations decide to become involved in political society, they have to follow the framework of a political coalition and decide either to support or to oppose the state; and certainly, as discussed previously, they tend to choose the former rather than the latter. Indonesia, on the other hand, has weak and short-term political coalitions that are conducive for the Islamic organizations to maintain their watchdog roles even when they have an affiliation with political parties. The vast fragmentation of political parties and the pragmatic reasons to form a coalition -mostly to win the presidential election- have created weak coalitions that are easy to dissolve. These political parties may support the government today, but they may oppose the government tomorrow. One positive impact from this situation is that a party can still criticize the state. Therefore, NU-Muhammadiyah and their affiliated parties, PKB and PAN, were able to criticize the state's proposal about the Mass Organization Law, even though the parties were actually allied with the state.

Comparing Islamic organizations in Malaysia and Indonesia highlights the complicated relationship between civil society, political society and the state. The contrast between Malaysia and Indonesia clearly show how three aspects; that is the political system, the political coalition, and the intervention of the state in the integration process of the organizations into political society, are significant factors in constructing this relationship. These three aspects also lead to different capabilities of Islamic organizations to oversee the state while playing roles in both civil society and political society.
Theoretically, this research both confirms and disproves the notion of neo-Tocquevilleans.

The electoral authoritarianism, the strong political coalition, and the non-independent integration process of Islamic organizations in civil society into political society, significantly limit the ability of Malaysian Islamic organizations to perform a supervisory function. The organizations in Malaysian civil society can fulfill this function to ensure the effective performance of the state only when they are separated from the political society. In some sense, this is in accordance with the neoTocquevillean argument that civil society, as a supporting system, should be disconnected from both political society and the state to perform effectively. The Indonesian case, however, challenges the neo-Tocquevillean notion.NU and Muhammadiyah have shown that it is possible for Islamic organizations to play their role as part of civil society whilst they have affiliations with political parties. These organizations can still play their watchdog roles to oversee the state and to protect the society from state tyranny, even though they are part of political society. Based on this analysis, the ability to oversee the state is a result of three main aspects: the electoral democracy, the independent process of Islamic organization into political society, and the weak political coalition.

\section{CONCLUSION}

Islamic organizations in Indonesia and Malaysia not only play significant roles in civil society, but also in political society. ABIM in Malaysia, and NU and Muhammadiyah in Indonesia are three major organizations that are closely connected with political parties. It is certainly not an ideal civil society as imagined by the neo-Tocquevilleans. According to neo-Tocquevilleans, civil society needs to be separated from political society in order for them to be able to objectively play the watchdog roles. The case of Malaysia, however, confirms the neo-Tocquevillean argument because it proves that organizations are able to optimally oversee the state only when they are independent from the state and the political parties. On the 
contrary, the Indonesian case opposes the neoTocquevillean idea since Islamic organizations effectively run their oversight functions both when they are independent and when they are linked with political parties.

This research has found three key aspects that influence the ability of Islamic organizations in Malaysia and Indonesia to perform an overseeing function when they are allied with political parties. These aspects are the political system, the political coalitions, and the integration process of the organizations into political society. In Malaysia, an electoral authoritarianism, a strong political coalition and a rigid integration process imposed by the state have eliminated the Islamic organizations' ability to criticize the state. In Indonesia, on the other hand, an electoral democracy, weak political coalitions, and autonomy in the integration process, have created independent and objective Islamic organizations in civil society which can remain independent and objective even when they become part of political society.

By juxtaposing the Islamic organizations in Malaysia and Indonesia, I have argued in this paper against the neo-Tocquevillean argument about the ideal form of civil society. The cases show that it is not impossible for the Islamic organizations in civil society to maintain their functions as a supporting structure to democratize the state and to oversee the state while they are in political society. This however, can only emerge under specific conditions, namely that the state is a democratic state-neither a pseudo-democracy nor an authoritarian state-, that the integration process of Islamic organizations into political society should be free from state intervention, and that the political coalition between state and political parties is not rigidly established.

\section{REFERENCES}

Alagappa, Muthiah. (2004). Civil Society and Political Change: An Analytical Framework. In Muthiah Alagappa(ed.), Civil Society and Political Change in Asia (p.25-6o). Stanford: Stanford University Press.

Ali, Mahrus\& M.F. Nurhuda Y. (2008) Pergulatan Membela yang Benar.Jakarta: Kompas.
Amal, Taufik Adnan \& Samsur Rizal P. (2004) Politik Syariat Islam. Jakarta: Pustaka Alvabet.

Assyaukanie, Luthfi. (2009). Islam and the Secular State in Indonesia. Singapore: Institute of Southeast Asian Studies (ISEAS).

Aziz, Azmi, \& Shamsul A. B. (2004).The Religious, the Plural, the Secular and the Modern: a Brief Critical Survey on Islam in Malaysia. Inter-Asia Cultural Studies 5(3), 34I-356.

Bruinessen, Martin Van. (1994). NU: Tradisi, Relasi-Relasi Kuasa, Pencarian Wacana Baru (Translated from the original book: Traditionalist Muslim in a Modernizing World: The Nahdlatul Ulama and Indonesia's New Order Politics, Factional Conflict and The Search for a New Discourse (Manuskrip)). Yogyakarta: LKIS Yogyakarta.

Buehler, Michael(2009). Islam and Democracy in Indonesia. Insight TurkeyII (4), 5I-63.

Case, William. (2006). Manipulative Skills: How Do Rulers Control the Electoral Arena." In Andreas Schedler (ed.), Electoral Authoritarianism: The Dynamics of Unfree Competition(p.95-II2). Colorado: Lynne Rienner Publisher, Inc., 2006.

Freedman, Amy L. (2009).Civil Society, Moderate Islam, and Politics in Indonesia and Malaysia." Journal of Civil Society 5 (2), I07-I27.

Gomez, Edmund Terence.(2007). Introduction: Resistance to Change -Malay Politics in Malaysia. In Edmund Terence Gomez(ed.).Politics in Malaysia: The Malay Dimension (p. I-23). New York: Routledge.

Hamid, Ahmad Fauzi bin Abdul.(2003). Inter-Movement Tension among Resurgent Muslims in Malaysia: Response to the State Clampdown on Darul Arqam in I994.Asian Studies Review 27 (3), 36I-387.

Hamid, Ahmad Fauzi bin Abdul. (2008). Islamist Realignments and the Rebranding of the Muslim Youth Movement of Malaysia. Contemporary Southeast Asia: A Journal of International and Strategic Affairs 30 (2), 215-240.

Hefner, Robert W. (200o). Civil Islam. New Jersey: Princeton University Press.

Lee, Jeff. (2004). The Failure of Political Islam in Indonesia: A Historical Narrative. Stanford Journal of East Asian Affairs 4(I), 85-I04.

Liow, Joseph Chinyong, and AfifPasuni. (2015). Islam, the State and Politics in Malaysia. In Meredith L. Weiss, (ed.), Routledge Handbook of Contemporary Malaysia (p. 50-59).New York: Routledge. 
Haris, Syamsuddin. I99I. PPP dan Politik Orde Baru. Jakarta: PT Gramedia Widiasarana Indonesia.

Hassan, Saliha. (2004). Islamic Non-Governmental Organizations. In Meredith L. Weiss and Saliha Hassan (eds.). Social Movements in Malaysia: From Moral Communities to NGOs (97-II4).New York: RoutledgeCurzon, 2004.

Hassan, Sharifah Zaleha Syed. (200I). Islamization and the Emerging Civil Society in Malaysia: A Case Study. In Nakamura Mitsuo, Sharon Siddique and Omar Farouk Bajunid (eds.).Islam \&Civil Society in Southeast Asia (76-88). Singapore: Institute of Southeast Asian Studies (ISEAS).

Hassan, Sharifah Zaleha Syed. (2009). Negotiating Islamism: the Experiences of the Muslim Youth Movement of Malaysia. Journal for Islamic Studies 29, 58-8I.

Hwang, Julie Chernov. (2009).Peaceful Islamist Mobilization in the Muslim World. New York: Palgrave.

Karakas, Cemal. (2007). Turkey: Islam and Laicism Between the Interests of State, Politics, and Society. Frankfurt: Peace Research Institute Frankfurt (PRIF).

Kartasasmita, Ginandjar. (2013). Managing Indonesia's Transformation. Singapore: World Scientific Publishing Co. Pte. Ltd.

King, Dwight Y. (2003). Half-hearted Reform: Electoral Institutions and the Struggle for Democracy in Indonesia. Connecticut: Praeger.

Lemiere, Sophie. (2007). Apostasy \& Islam Civil Society in Malaysia. International Institute for Study of Islam in the Modern World (ISIM) Review 20, 46-47.

Liow, Joseph Chinyong. (2009). Piety and Politics: Islamism in Contemporary Malaysia. Oxford: Oxford University Press, Inc.

Maidinier, Remy. (2015). Islam and Politics in Indonesia: The Masyumi Party between Democracy and Integralism. Singapore: National University of Singapore (NUS) Press.

Mietzner, Marcus. (2009). Military Politics, Islam and the State in Indonesia: from Turbulent Transition to Democratic Consolidation. Singapore: Institute of Southeast Asian Studies (ISEAS).

Migdal, Joel S. (1998).Strong Societies and Weak States: State-Society Relations and State Capabilities in the Third World. New Jersey: Princeton University Press.

Mitsuo, Nakamura. (200I). Introduction. In Nakamura Mitsuo, Sharon Siddique and Omar Farouk Bajunid (eds.),Islam \& Civil Society in Southeast Asia. Singapore: Institute of Southeast Asian Studies (ISEAS).

Bakar, Mohamad Abu. (200I).Islam, Civil Society, and Ethnic Relations in Malaysia. In Nakamura Mitsuo, Sharon Siddique and Omar Farouk Bajunid (eds.).Islam \&Civil Society in Southeast Asia (57-75).Singapore: Institute of Southeast Asian Studies (ISEAS).

Putnam, Robert D. (I993). Making Democracy Works: Civil Traditions in Modern Italy. New Jersey: Princeton University Press.

Riley, Dylan. (2005). Civic Association and the Authoritarian Regimes in Interwar Europe: Italy and Spain in Comparative Perspective. American Sociological Review 70 (2), 288-3Io.

Stepan, Alfred C. (1988). Rethinking Military Politics: Brazil and the Southern Cone. New Jersey: Princeton University Press.

Tajuddin, Muhammad Saleh (2012). The Discourse of Islamic Civil Society in Indonesia during The Reformation. Journal of Islamic Civilization in Southeast Asia I (I), I52-I85.

Tocqueville, Alexis de. (2004).Democracy in America. New York: Literary Classics of the United States.

Ufen, Andreas. (2006). Political Parties in PostSuharto Indonesia: Politik Aliran and 'Philippinisation'. GIGA Working Papers 37, I-35.

(2009). Mobilising Political Islam: Indonesia and Malaysia Compared. Commonwealth \& Comparative Politics, 47(3), 308-333.

Warjio and Evi Novida Ginting. (2006). Konflik Penguasa dengan Partai Politik Islam. JurnalHarmoniSosialı, (I), 36-45.

Weiss, Meredith L. (2004). Malaysia: Construction of Counterhegemonic Narratives and Agendas." In Muthiah Alagappa (ed.),Civil Society and Political Change in Asia (259-29I).Stanford: Stanford University Press.

(2006). Protest and Possibilities: Civil Society and Coalitions for Political Change in Malaysia. California: Stanford University Press.

(2013, July 2). DPR Sahkan UU Ormas. BBC Indonesia. Retrieved from http://www.bbc.co.uk/ indonesia/berita_indonesia/2013/07/130702_ dpr_rapat_ruuormas.

(20I3, April II). Muhammadiyah-NU Sepakat Tolak RUU Ormas. Retrieved fromhttp://www. suaramerdeka.com/vi/index.php/read/ cetak/20I3/04/II/22I457/MuhammadiyahNU-Sepakat-Tolak-RUU-Ormas. 
(2013, July 22). NU Tak Ikut Gugat UU Ormas. Retrieved fromhttp://www. nu.or.id/a,public-m,dinamic-s, detailids,44-id,46o I 8-lang,id-c,nasionalt,NU+Tak+lkut+Gugat+UU+Ormas-.phpx.

(2013, July 2). RUU Ormas Disahkan, Delapan Pasal Alami Perubahan. Retrieved from http://nasional.kompas.com/read/2013/o7/o2/I425557/ RUU.Ormas.Disahkan.Delapan.Pasal.Alami. Perubahan. 